\title{
PENGARUH PERKUATAN MORTAR JAKET DENGAN VARIASI JARAK SENGKANG BAMBU PADA KOLOM BETON BERTULANG
}

\author{
M. Ainur Rofiq ${ }^{1}$,Christin Remayanti Nainggolan ${ }^{2}$, Ari Wibowo $^{2}$, Indradi Wijatmiko $^{2}$ \\ ${ }^{1}$ Mahasiswa Program Studi Sarjana / Jurusan Teknik Sipil / Universitas Brawijaya \\ ${ }^{2}$ Dosen / Jurusan Teknik Sipil / Universitas Brawijaya \\ *Korespondensi : ainurrofik30@gmail.com
}

\begin{abstract}
A building consists of several structural elements, one of them is a column that has the function to distribute the entire load of the building towards the foundation. If in the working process is done poorly, the column structure will fail. In addition, the structure of the building that has been established is sometimes not function appropriately based on the initial plan, so the load that works on the structure of the building can exceed limits that are previously calculated. Then, the reinforcement of the column is required to be functioned according to the previous planning. In this case, we use the retrofit column code A.5 and B.5 is a retrofit column that uses 4 pieces and 8 pieces of bamboo longitudinal with a size of $10 \times 10 \mathrm{~mm}$ and $10 \times 5$ $\mathrm{mm}$ with a distance between $7 \mathrm{~cm}$ transversal reinforcement, compared to a retrofit column code A.6 and B.6 is a retrofit column that uses longitudinal reinforcement of bamboo as many as 4 pieces and 8 pieces with a size of $10 \times 10 \mathrm{~mm}$ and $10 \times 5 \mathrm{~mm}$ with a distance between transversal reinforcement $11 \mathrm{~cm}$. The column was tested by using a compression test machine to obtain the value of the compressive force and dial gauge to obtain the deflection value. Testing of compressive strength was not carried out in the initial column, but only in the retrofit column. The results of the study between variations of A5 and A6 showed that variations in A5 had an increase in the maximum compressive force of $61.78 \%$ while variations in A6 increased by $59.86 \%$, it is concluded that A5 was more effective than A6. Whereas for the research between variations of B5 and B6 it was found that variations in B5 had an increased maximum in compressive force of 48,51\%, it is concluded that $B 5$ was more effective than B6.
\end{abstract}

Keywords: concrete jacket, compressive force, ductility, effectiveness, elastic modulus, stiffness.

\section{PENDAHULUAN}

Sebuah bangunan terdiri dari beberapa elemen struktur, dimana salah satunya adalah kolom. Kolom merupakan komponen struktur utama dari sebuah bangunan yang mempunyai fungsi sebagai penyalur seluruh beban bangunan diatasnya menuju pondasi. Oleh sebab itu kolom menjadi struktur terpenting dari sebuah bangunan. Sehingga apabila kolom dalam struktur bangunan lemah maka akan beresiko mengalami kegagalan konstruksi.

Semakin berkembangnya konstruksi di Indonesia, kebutuhan akan konstruksi bangunan meningkat seiring waktu berjalan. Tidak hanya meningkat dalam pembangunan bangunan baru tetapi banyak terjadi perubahan fungsi bangunan. Dari perbubahan fungsi bangunan tersebut struktur kolom yang menerima dampak yang dari perubahan beban yang bekerja, sehingga apabila kolom tidak di perbaiki maka akan terjadi kolom lemah dan akan menimbulkan kegagalan struktur bangunan. Oleh sebab itu diperlukan perkuatan kolom dengan metode mortar jacketing dengan melapisi kolom asli dengan lapisan tambahan berupa mortar serta penambahan tulangan menggunakan bambu petung sebagai tulangan utama dan bambu apus sebagai Sengkang. Digunakan bambu sebagai tulangan dikarenakan bambu lebih murah dan ramah lingkungan serta memiliki kuat tarik 100-400 Mpa lebih besar daripada kuat tarik baja mutu sedang. Pengujian menggunakan beban aksial sehingga dalam penelitian ini akan didapatkan gaya tekan, modulus elastisitas, kekakuan dan daktilitas yang lebih efektif dari kolom lemah yang telah diretrofit. Parameter yang sudah ditentukan untuk mengetahui pengaruh jarak sengkang pada kolom lemah yang telah diretrofit. 


\section{TINJAUAN PUSTAKA}

Beton ialah campuran dari semen portland yang dicampur dengan agregat halus, agregat kasar, dan air. Beton dapat memakai bahan campuran tambahan (admixture). Pada beton biasanya terdapat tulangan yang berfungsi sebagai penahan gaya tarik yang bekerja pada beton. Beton yang kuat terhadap gaya tekan dan lemah terhadap tarik, maka diperlukan tulangan untuk menahan gaya tarik yang disebabkan beban - beban yang bekerja. [1]

Mortar adalah bahan bangunan yang terdiri dari agregat halus, bahan perekat serta air, dan diaduk sampai homogen, Mortar memiliki harga yang murah, tahan lama dan mudah dikerjakan.[2]

Bambu dipilih sebagai material tulangan karena bambu merupakan produk hasil alam yang renewable, murah, mudah tumbuh, mudah di tanam, dapat mereduksi efek global warming serta memiliki kuat tarik sangat tinggi yang dapat dipersaingkan dengan baja.

Tabel 1. Tegangan tarik bambu kering oven tanpa nodia dan dengan nodia

\begin{tabular}{|c|c|c|}
\hline \multirow{2}{*}{ Jenis Bambu } & \multicolumn{2}{|c|}{ Tegangan Tarik (Mpa) } \\
\cline { 2 - 3 } & Tanpa Nodia & Dengan Nodia \\
\hline Ori & 291 & 128 \\
\hline Petung & 190 & 116 \\
\hline Wulung & 166 & 147 \\
\hline Tutul & 216 & 74 \\
\hline Apus & 151 & 55 \\
\hline
\end{tabular}

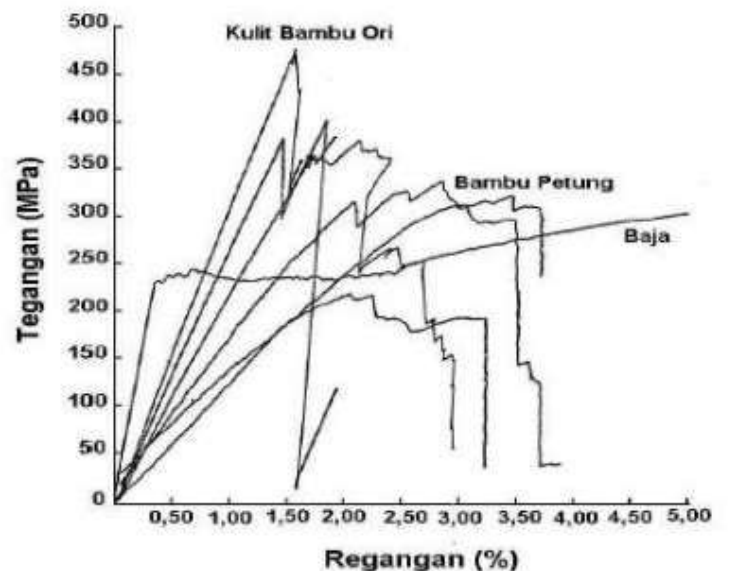

Gambar 1. Hubungan tegangan-regangan bambu dan baja.

Sumber : [3]

Dari Gambar 1 didapatkan bahwa bambu ori memiliki kekuatan yang cukup tinggi dari nilai tegangan leleh baja. Selain itu rata-rata dari bambu petung juga lebih besar dari tegangan leleh baja.



Gambar 2. Grafik gaya tekan dan deformasi material yang dibebani aksial

Tulangan transversal atau sengkang pada kolom memiliki pengaruh pada kekuatan penampangnya sehingga akan berkurang bersamaan dengan timbulnya masalah tekuk (buckling) yang dihadapi. Pada kolom, eksentrisitas dapat terjadi akibat timbulnya momen yang disebabkan oleh pelaksanaan pemasangan yang kurang sempurna, ataupun penggunaan mutu bahan yang tidak merata. Semakin pendek jarak sengkang pada kolom semakin besar kekuatan kolom tersebut.

Efektifitas kekangan dari kolom erat kaitannya dengan pengaruh luas efektif yang tidak mengalami kekangan. Semakin kecil luas daerah yang tidak mengalami kekangan, maka hal ini akan meningkatkan daktilitas dari kolom.

\section{Zona Kekangan Efektif}
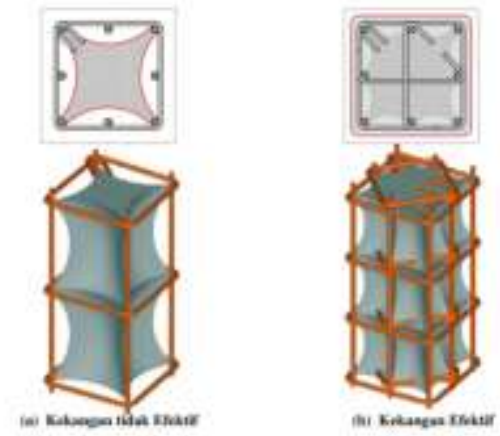

Gambar 3. Jarak antar sengkang mempengaruhi efektifitas pengekangan Sumber : [4]

\subsection{Kuat Beban Aksial Kolom}

Rumus untuk kolom bertulang baja dapat dilihat pada persamaan (1).

$P_{n(\max )}=0.85 f^{\prime}{ }_{c}\left(A_{g}-\right.$ $\left.A_{s t}\right)+(f y \cdot A s t)$. 
Rumus untuk kolom retrofit bertulang bambu dapat dilihat pada persamaan (2).

$$
\begin{array}{ll}
P_{n(\max )} & =f^{\prime \prime}{ }_{c} x A g \\
f^{\prime \prime}{ }_{c} & =K f_{c}{ }^{\prime} \ldots . \\
K & =1+\frac{\rho_{s f_{y h}}}{f_{c^{\prime}}}
\end{array}
$$

Sumber : [5]

Keterangan :

$\mathrm{Pn}=$ kuat beban aksial nominal pada eksentrisitas yang diberikan $(\mathrm{kN})$

$\mathrm{Ag}=$ luas penampang bruto beton $\left(\mathrm{mm}^{2}\right)$

Ast $=$ luas tulangan $\left(\mathrm{mm}^{2}\right)$

f' $c=$ Tegangan Maksimum Beton $(\mathrm{MPa})$

$\mathrm{f}^{\prime} \mathrm{c}=$ kuat tekan beton $(\mathrm{MPa})$

fy = tegangan leleh dari tulangan longitudinal (MPa)

fyh = tegangan leleh dari tulangan transversal (MPa)

$\rho s=$ Rasio tulangan trasversal

\subsection{Kekakuan dan Modulus Elastisitas Kolom}
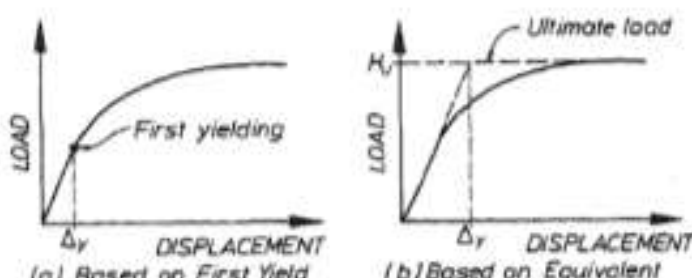

(o) Bosed on Eirst Yiedd

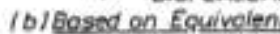

Flosto-piastic Yeld


Elasto-pios

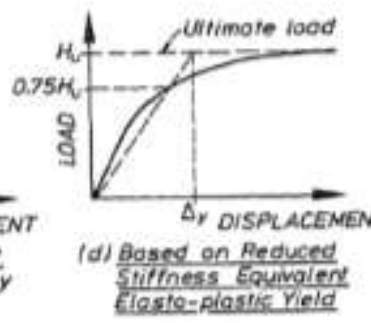

Gambar 4. Beberapa Alternatif Pengambilan Lendutan pada Titik Leleh

Lendutan pada titik leleh diambil dari titik potong beban yang mana beban diambil $75 \%$ dari beban ultimate.

Rumus modulus elastisitas dapat dilihat pada persamaan (3).

$E=\frac{\sigma}{\varepsilon}$.

Keterangan :

$$
\begin{array}{ll}
\mathrm{E} & =\text { Modulus Elastisitas }\left(\mathrm{kN} / \mathrm{mm}^{2}\right) \\
\sigma & =\text { Tegangan }\left(\mathrm{kN} / \mathrm{mm}^{2}\right) \\
\varepsilon & =\text { Regangan }
\end{array}
$$

Pada analisis data mencari nilai modulus elastisitas kolom asli dan kolom retrofit, nilai tegangan didapatkan dari $75 \%$ nilai gaya tekan maksimum dibagi dengan luas penampang kolom serta nilai regangan diambil dari nilai defleksi dari $75 \%$ gaya tekan maksimum dibagi dengan panjang mula - mula kolom yakni $300 \mathrm{~mm}$.

Rumus kekakuan dapat dilihat pada persamaan (4).

$k=\frac{P}{\Delta}$.

Keterangan :

$\mathrm{k}=$ Kekakuan Struktur $(\mathrm{kN} / \mathrm{mm})$

$\mathrm{P} \quad=$ Gaya Tekan $(\mathrm{kN})$

$\Delta \quad=\operatorname{Defleksi}(\mathrm{mm})$

Pada analisis data untuk mencari nilai kekakuan kolom asli dan kolom retrofit digunakan metode Park (1988) yaitu, untuk nilai gaya tekan diambil dari $75 \%$ dari nilai gaya tekan maksimum dan nilai defleksi diambil pada $75 \%$ dari nilai gaya tekan maksimum.

\subsection{Tegangan dan Regangan Kolom}

Rumus tegangan pada kolom bertulang dapat dilihat pada persamaan (5).

$\sigma=\frac{P}{A}$

Keterangan :

$P=$ gaya tekan $(\mathrm{kN})$

$A=$ luas tampang melintang $\left(\mathrm{mm}^{2}\right)$

Rumus regangan pada kolom bertulang dapat dilihat pada persamaan (6).

$\varepsilon=\frac{\Delta L}{L}$

Keterangan :

$\Delta L=$ perubahan panjang akibat beban $\mathrm{P}(\mathrm{mm})$

$L=$ panjang semula $(\mathrm{mm})$

\subsection{Daktilitas Kolom}

Daktilitas merupakan sifat dari suatu bahan yang mampu mengalami perubahan bentuk secara permanen tanpa adanya kerusakan. Daktilitas diperlukan pada proses perencanaan beban terhadap suatu bahan guna mencegah kerusakan yang tidak terdeteksi apabila suatu bahan menerima beban yang besar secara tiba-tiba.

Rumus daktilitas dapat dilihat pada persamaan (7).

$\mu_{\Delta=\frac{\Delta u}{\Delta y}}$

Keterangan :

$\mu \Delta=$ Nilai daktilitas

$\Delta \mathrm{u}=$ Deformasi ultimate $(\mathrm{cm})$

$\Delta \mathrm{y}=$ Deformasi leleh $(\mathrm{cm})$ 


\section{METODOLOGI PENELITIAN}

Tabel 2. Variasi tulangan bambu pada kolom retofit

\begin{tabular}{|c|c|c|c|c|}
\hline \multirow{2}{*}{$\begin{array}{c}\text { Kode } \\
\text { Kolom }\end{array}$} & \multirow{2}{*}{$\begin{array}{c}\text { Tulangan } \\
\text { Bambu }\end{array}$} & \multirow{2}{*}{ rho } & \multicolumn{2}{|c|}{ Sengkang bambu } \\
\cline { 4 - 5 } & & & 5 & 6 \\
\cline { 4 - 5 } & & Jarak 7 cm & Jarak $11 \mathrm{~cm}$ \\
\hline $\mathrm{A}$ & 4 bh $10 \times 10$ & 1,23 & 3 buah & 3 buah \\
\hline $\mathrm{B}$ & 8 bh $10 \times 5$ & 1,23 & 3 buah & 3 buah \\
\hline
\end{tabular}

Tabel 3. Jumlah benda uji

\begin{tabular}{|c|c|}
\hline Varian & Jumlah \\
\hline Benda uji silinder sampel kolom asli & 4 buah \\
\hline Benda uji kolom asli & 12 buah \\
\hline Benda uji silinder sampel kolom retrofit & 4 buah \\
\hline Benda uji kolom retrofit kode A5 & 3 buah \\
\hline Benda uji kolom retrofit kode B5 & 3 buah \\
\hline Benda uji kolom retrofit kode A6 & $3 \mathrm{bush}$ \\
\hline Benda uji kolom retrofit kode B6 & $3 \mathrm{buah}$ \\
\hline
\end{tabular}

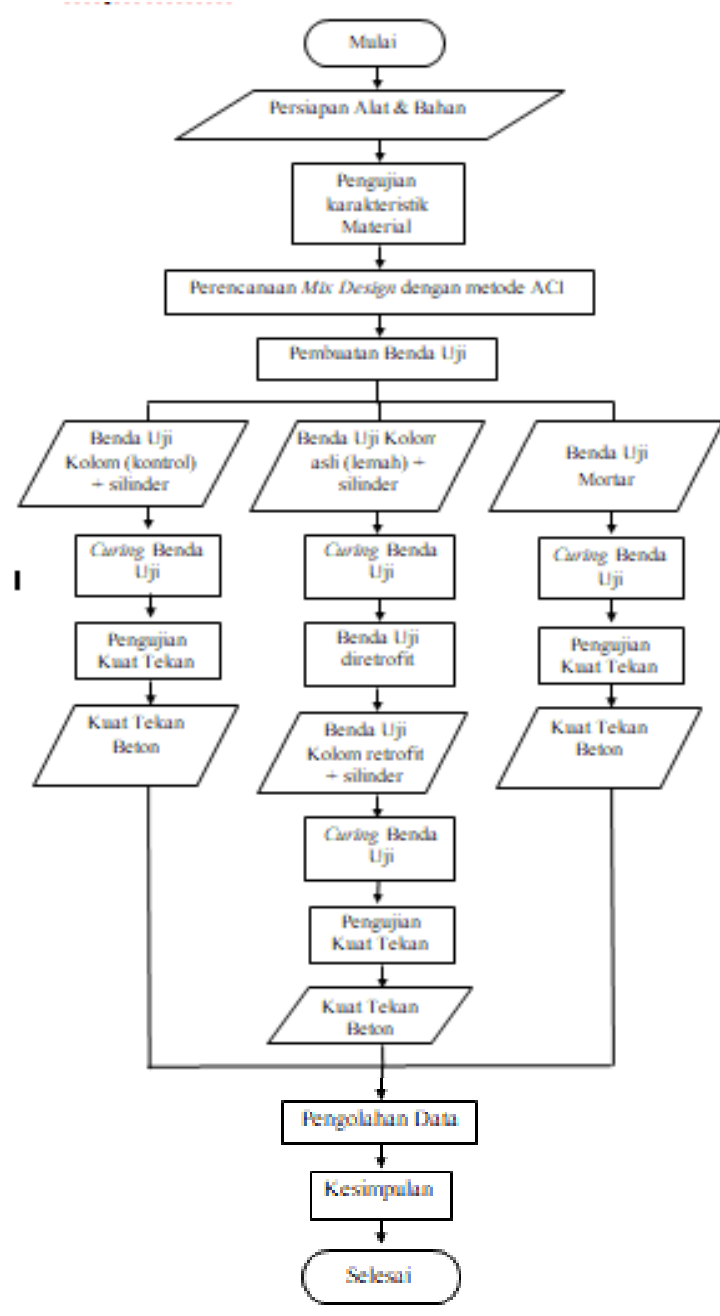

\section{HASIL DAN PEMBAHASAN}

Pada pengujian kuat tekan beton silinder diambil 2 benda uji setiap variasi kolom. Hasil uji tekan beton silinder dapat dilihat pada Tabel 4 dan Tabel 5, sedangkan hasil pengujian kuat tekan mortar dapat dilihat pada Tabel 6.

Tabel 4. Hasil uji kuat tekan beton benda uji silinder (sampel benda uji kolom asli)

\begin{tabular}{|c|c|c|c|c|c|}
\hline $\begin{array}{c}\text { Kode Benda } \\
U_{j i}\end{array}$ & Umur & Berat & $\begin{array}{c}\text { Beban } \\
\text { Maksimum }\end{array}$ & $\begin{array}{l}\text { Gaya } \\
\text { Tekan }\end{array}$ & $\begin{array}{c}\text { Gaya Tekan } \\
\text { Rata-Rata }\end{array}$ \\
\hline & (Hari) & $(\mathrm{kg})$ & $(\mathrm{kN})$ & (Mpa) & (Mpa) \\
\hline A5-A6 (1) & \multirow{4}{*}{28} & 12,30 & 382,3 & 21,63 & \multirow{2}{*}{17,95} \\
\hline $\mathrm{A} 5-\mathrm{A} 6(2)$ & & 12,55 & 252,1 & 14,27 & \\
\hline B5 -B6 (1) & & 12,45 & 321,0 & 18,16 & \multirow{2}{*}{21,06} \\
\hline B5 -B6 (2) & & 12,50 & 423,3 & 23.95 & \\
\hline
\end{tabular}

Tabel 5. Hasil uji kuat tekan beton benda uji silinder (sampel benda uji kolom kontrol)

\begin{tabular}{cccccc}
\hline \multirow{2}{*}{$\begin{array}{c}\text { Kode Benda } \\
\mathrm{Uji}_{\mathrm{ji}}\end{array}$} & Slump & Berat & $\begin{array}{c}\text { Beban } \\
\text { Maksimum }\end{array}$ & $\begin{array}{c}\text { Gaya } \\
\text { Tekan }\end{array}$ & $\begin{array}{c}\text { Gaya Tekan } \\
\text { Rata-Rata }\end{array}$ \\
\cline { 2 - 6 } & $(\mathrm{cm})$ & $(\mathrm{kg})$ & $(\mathrm{kN})$ & $(\mathrm{Mpa})$ & $(\mathrm{Mpa})$ \\
\hline Kontrol & 11 & 12,4 & 242,6 & 13,73 & 13,73 \\
\hline
\end{tabular}

Tabel 6. Hasil uji kuat tekan beton benda uji mortar (sampel benda uji kolom retrofit)

\begin{tabular}{|c|c|c|c|c|c|c|}
\hline \multirow[t]{2}{*}{ No } & \multirow{2}{*}{$\begin{array}{c}\text { Kode Benda } \\
\text { Uji }\end{array}$} & \multirow{2}{*}{$\begin{array}{l}\text { Umur } \\
\text { (Hari) }\end{array}$} & Berat & $\begin{array}{c}\text { Beban } \\
\text { Maksimum }\end{array}$ & Gaya Telkan & \multirow{2}{*}{$\begin{array}{c}\text { Gaya Telkan Rata- } \\
\text { Rata } \\
\text { (Mpa) }\end{array}$} \\
\hline & & & (kg) & $(\mathrm{ENN})$ & (Mps) & \\
\hline \multirow{3}{*}{1} & $\mathrm{~A} 5$ (1) & \multirow{12}{*}{28} & 304,30 & 62,00 & 24,80 & \multirow{3}{*}{22,56} \\
\hline & $\mathrm{A} 55(2)$ & & 290,10 & 40,00 & 16,00 & \\
\hline & A5 (3) & & 331,60 & 67,20 & 26,88 & \\
\hline \multirow{4}{*}{2} & A6 (1) & & 285,10 & 68,50 & 27,40 & \multirow{4}{*}{32,33} \\
\hline & $\mathrm{A} 6(2)$ & & 276,30 & 74,00 & 29,60 & \\
\hline & A6 (3) & & 279,70 & 100,00 & 40,00 & \\
\hline & B5 (1) & & 281,00 & 104,00 & 41,60 & \\
\hline \multirow[t]{3}{*}{3} & B5 (2) & & 272,90 & 72,40 & 28,96 & \multirow[t]{2}{*}{33,25} \\
\hline & B5 (3) & & 292,00 & 73,00 & 29,20 & \\
\hline & B6 (1) & & 272,90 & 58,60 & 23,44 & \\
\hline \multirow[t]{2}{*}{4} & B6 (2) & & 281,40 & 70,20 & 28,08 & \multirow[t]{2}{*}{26,19} \\
\hline & B6 (3) & & 259,50 & 67,60 & 27,04 & \\
\hline
\end{tabular}

Hasil pengujian kuat beban aksial kolom asli dan kolom retrofit dapat dilihat pada Tabel 7, Tabel 8, dan Tabel 9.

Tabel 7. Hasil kuat beban aksial kolom asli secara teoritis (tidak dilakukan pengujian beban aksial)

\begin{tabular}{cccc}
\hline \multirow{2}{*}{ No } & $\begin{array}{c}\text { Kode Benda } \\
\text { Uji Kolom Asli }\end{array}$ & $\begin{array}{c}\text { Gaya Tekan Beton } \\
\text { (fC) }\end{array}$ & $\begin{array}{c}\text { Kelruatan Nominal Kolom } \\
\text { (Pn) Secara Teoritis }\end{array}$ \\
\cline { 3 - 4 } & & $(\mathrm{Mpa})$ & $\mathrm{kN}$ \\
\hline 1 & A5 & 17,95 & 248,01 \\
2 & A6 & 17,95 & 248,01 \\
3 & B5 & 21,06 & 285,86 \\
4 & B6 & 21,06 & 285,86 \\
\hline
\end{tabular}

Gambar 4. Diagram alir tahapan penelitian 
Tabel 8. Hasil kuat beban aksial kolom kontrol

\begin{tabular}{|c|c|c|c|c|}
\hline No & $\begin{array}{c}\text { Kode } \\
\text { Benda } \\
\text { Uji }\end{array}$ & $\begin{array}{l}\text { 'Kuat Telsan } \\
\text { Beton (fC') }\end{array}$ & $\begin{array}{c}\text { Kuat Teksn } \\
\text { Kolom Asli } \\
\text { Malssimum } \\
\text { Teoritis }\end{array}$ & $\begin{array}{c}\text { Keluatan } \\
\text { Maksimum } \\
\text { Kolom (Pu) } \\
\text { Secara Aktual }\end{array}$ \\
\hline & & (Mpa) & $(\mathrm{kN})$ & $(\mathrm{kN})$ \\
\hline 1 & Kontrol & 13,73 & 196,62 & 270,20 \\
\hline
\end{tabular}

Tabel 9. Hasil kuat beban aksial kolom retrofit

\begin{tabular}{ccccc}
\hline \multirow{2}{*}{ No } & $\begin{array}{c}\text { Kode } \\
\text { Benda Uji } \\
\text { Kolom } \\
\text { Retrofit }\end{array}$ & $\begin{array}{c}\text { Gaya Teksan } \\
\text { Beton (f́) }\end{array}$ & $\begin{array}{c}\text { Keluatan Nominal } \\
\text { Kolom (Pn) Secara } \\
\text { Teoritis }\end{array}$ & $\begin{array}{c}\text { Keluatan } \\
\text { Malssimum } \\
\text { Kolom (Pu) } \\
\text { Secara Aktual }\end{array}$ \\
\cline { 3 - 5 } & A5 & 22,56 & lNN & kN \\
\hline 1 & A6 & 32,33 & 419,313 & 437,05 \\
2 & A6 & 33,25 & 539,678 & 431,94 \\
3 & B5 & 33,070 & 393,21 \\
4 & B6 & 26,19 & 455,359 & 401,20 \\
\hline
\end{tabular}

Dari penelitian yang sudah dilakukan kuat beban aksial kolom asli dengan kolom retrofit diperoleh hasil kuat beban aksial maksimum pada kolom asli yang dinyatakan dengan menggunakan kuat beban aksial maksimum kolom kontrol yang dapat dilihat pada tabel 8 yaitu sebesar $270,2 \mathrm{kN}$. Sedangkan hasil kuat beban aksial maksimum pada kolom retrofit dapat dilihat pada tabel 9, yaitu kolom retrofit A.5 sebesar $437,05 \mathrm{kN}$, jadi dapat disimpulkan bahwa terjadi peningkatan kuat beban aksial maksimum kolom retrofit A.5 sebesar $61,75 \%$ dari kuat beban aksial maksimum kolom kontrol. Kolom retrofit A.6 sebesar 431,94 kN, jadi dapat disimpulkan bahwa terjadi peningkatan pada kuat beban aksial kolom retrofit A.6 sebesar 59,86\% dari kuat beban aksial maksimum kolom kontrol. Adapun kolom retrofit B.5 sebesar 393,21 kN, jadi dapat disimpulkan bahwa terjadi peningkatan pada kuat beban aksial kolom retrofit B.5 sebesar $45,52 \%$ dari kuat beban aksial maksimum kolom kontrol. Adapun kolom retrofit B.6 sebesar 401,20 kN, jadi dapat disimpulkan bahwa terjadi peningkatan pada kuat beban aksial kolom retrofit B.6 sebesar 48,48\% dari kuat beban aksial maksimum kolom kontrol.

Tabel 10. Perbandingan hasil penelitian kolom retrofit A5 dengan kolom retrofit A6

\begin{tabular}{ccccccc}
\hline NO & $\begin{array}{c}\text { Kode } \\
\text { Benda Uji } \\
\text { Kolom }\end{array}$ & $\begin{array}{c}\text { Peningkatan } \\
\text { Gaya Tekan } \\
(\%)\end{array}$ & $\begin{array}{c}\text { Gaya Tekan } \\
\text { Maksimum } \\
(\mathrm{kN})\end{array}$ & $\begin{array}{c}\text { Kekakuan } \\
(\mathrm{kN} / \mathrm{mm})\end{array}$ & $\begin{array}{c}\text { Modulus } \\
\text { Elastisitas } \\
\left(\mathrm{kN} / \mathrm{mm}^{2}\right)\end{array}$ & $\begin{array}{c}\text { Peningkatan } \\
\text { Daktilitas } \\
(\%)\end{array}$ \\
\hline 1 & A.5 & 61,78 & 437,05 & 204,09 & 4,25 & $60,65 \%$ \\
2 & A.6 & 59,89 & 431,94 & 175,64 & 3,47 & $26,84 \%$ \\
\hline
\end{tabular}

Tabel 11. Perbandingan efektifitas kolom A5 dengan kolom retrofit A6

\begin{tabular}{cccccc}
\multicolumn{6}{c}{ dengan kolom retrofit A6 } \\
\hline No & $\begin{array}{c}\text { Kode } \\
\text { Benda } \\
\text { Uji } \\
\text { Kolom }\end{array}$ & $\begin{array}{c}\text { Peningkatan } \\
\text { Gaya Tekan } \\
\text { Maksimum } \\
(\%)\end{array}$ & $\begin{array}{c}\text { Efektifitas } \\
(\%)\end{array}$ & $\begin{array}{c}\text { Peningkatan } \\
\text { Daktilitas } \\
(\%)\end{array}$ & $\begin{array}{c}\text { Efektifitas } \\
(\%)\end{array}$ \\
\hline 1 & A.5 & 61,78 & 3,15 & 60,65 & 125,96 \\
\hline 2 & A.6 & 59,89 & & 26,84 & \\
\hline
\end{tabular}

Dari Tabel 10 dan Tabel 11, dapat disimpulkan bahwa berdasarkan parameter kuat tekan kolom retrofit A.5 lebih efektif dibandingkan kolom retrofit A.6 hal ini bisa di lihat dari peningkatan efektifitas kuat tekan A.5 ke A.6 sebesar 3,15\%. Sedangkan untuk parameter daktilitas mengalami peningkatan juga untuk kolom retrofit A.5 ke A.6 meningkat sebesar $125,96 \%$

Hal ini dikarenakan karena kolom retrofit A.5 memiliki jarak sengkang yang lebih rapat dibandingkan kolom retrofit A.6, sehingga efek kekangan yang diberikan oleh kolom retrofit A5 lebih besar dibandingkan dengan kolom retrofit A.6.

Tabel 12. Perbandingan hasil penelitian kolom retrofit B.5 dengan kolom retrofit B.6

\begin{tabular}{ccccccc}
\hline NO & $\begin{array}{c}\text { Kode } \\
\begin{array}{c}\text { Benda Uji } \\
\text { Kolom }\end{array}\end{array}$ & $\begin{array}{c}\text { Peningkatan } \\
\text { Gaya Tekan } \\
(\%)\end{array}$ & $\begin{array}{c}\text { Gaya } \\
\text { Tekan } \\
\text { Maksimum } \\
(\mathrm{kN})\end{array}$ & $\begin{array}{c}\text { Kekakuan } \\
(\mathrm{kN} / \mathrm{mm})\end{array}$ & $\begin{array}{c}\text { Modulus } \\
\text { Elastisitas } \\
\left(\mathrm{kN} / \mathrm{mm}^{2}\right)\end{array}$ & $\begin{array}{c}\text { Peningkatan } \\
\text { Daktilitas } \\
(\%)\end{array}$ \\
\hline 1 & B.5 & 45,55 & 393,21 & 174,72 & 3,640 & $60,85 \%$ \\
2 & B.6 & 48,51 & 401,20 & 175,99 & 3,667 & $43,57 \%$ \\
\hline
\end{tabular}

Tabel 13. Perbandingan efektifitas kolom B.5 dengan kolom retrofit B.6

\begin{tabular}{cccccc}
\hline NO & $\begin{array}{c}\text { Kode } \\
\text { Benda } \\
\text { Uji } \\
\text { Kolom }\end{array}$ & $\begin{array}{c}\text { Peningkatan } \\
\text { Gaya Tekan } \\
\text { Maksimum } \\
(\%)\end{array}$ & $\begin{array}{c}\text { Efektifitas } \\
(\%)\end{array}$ & $\begin{array}{c}\text { Peningkatan } \\
\text { Daktilitas } \\
(\%)\end{array}$ & $\begin{array}{c}\text { Efektifitas } \\
(\%)\end{array}$ \\
\hline 1 & B.5 & 45,55 & $-6,09$ & $60.85 \%$ & 39,67 \\
2 & B.6 & 48,51 & & $43.57 \%$ & \\
\hline
\end{tabular}

Berdasarkan data yang diperoleh pada Tabel 12 dan Tabel 13, maka dapat diperoleh kesimpulan bahwa berdasarkan parameter kuat tekan maksimum, maka kolom retrofit B.5 kurang efektif dalam penggunaannya dibandingkan dengan kolom retrofit B.6, hal ini dikarenakan efektifitas peningkatan gaya tekan kolom retrofit B.5 lebih rendah sebesar 6,09\% dibandingkan kolom retrofit B.6.

Namun, daktilitas yang dimiliki kolom B.5 lebih besar dibandingkan dengan kolom retrofit B.6, dimana kolom B.5 memiliki efektifitas lebih besar sebesar 39,67\% dibandingkan kolom retrofit B.6. Hal ini dikarenakan karena kolom retrofit B.5 memiliki jarak sengkang yang lebih rapat, sehingga efek 
kekangan yang diberikan oleh kolom B.5 lebih besar dibandingkan dengan kolom retrofit B.6. Oleh karena itu, jika mengacu dari efektifitas kekangan kolom, maka kolom retrofit B.5 lebih efektif digunakan dalam perbaikan ini.

Berdasarkan hasil tersebut, maka diperoleh kesimpulan bahwa kolom retrofit B.5 lebih efektif dibandingkan dengan kolom retrofit B.6, hal ini dikarenakan efektifitas peningkatan daktilitas B.5 jauh lebih tinggi dibandingkan B.6

\section{PENUTUP}

\subsection{Kesimpulan}

Dari hasil analisis dan pembahasan mengenai penelitian kolom retrofit yang telah dilakukan, maka penelitian ini dapat disimpulkan bahwa :

1. Hasil kuat tekan maksimum dari keempat variasi kolom retrofit menunjukan peningkatan dibandingkan dengan kolom kontrol. Yang mana variasi kolom retrofit A5 meningkat sebesar 61,78\%, kolom retorift A6 meningkat sebesar 59,89\%, kolom retorift B5 meningkat sebesar 45,55\%, dan kolom retorift B6 meningkat sebesar $48,51 \%$ dibandingkan kolom kontrol. Dari hasil yang diperoleh kemudian dibandingkan antara kolom retrofit A5 dengan A6 menunjukan bahwa kolom retrofit A5 dengan jarak sengkang $7 \mathrm{~cm}$ memiliki nilai gaya tekan maksimum yang lebih tinggi daripada kolom retrofit A6 yang memiliki jarak sengkang $11 \mathrm{~cm}$. Sedangkang perbandingan antara kolom retrofit B5 dengan B6 menunjukan bahwa kolom retrofit B6 dengan jarak sengkang 11 $\mathrm{cm}$ lebih tinggi kuat tekannya daripada kolom retrofit B5 yang memiliki jarak sengkang $7 \mathrm{~cm}$

2. Hasil nilai modulus elastisitas dan kekakuan keempat variasi kolom retrofit menunjukan peningkatan dibandingkan kolom kontrol. Yang mana kolom retrofit A5 meningkat sebesar masing-masing 40,66 \% dan $30,77 \%$, kolom retrofit A6 meningkat sebesar masing-masing 14,64 \% dan $12,53 \%$, kolom retrofit B5 meningkat sebesar masing-masing 20,42 \% dan $11,95 \%$, dan kolom retrofit B6 meningkat sebesar masing-masing $21,29 \%$ dan $12,76 \%$. Dari hasil yang diperoleh kemudian dibandingkan antara kolom retrofit A5 dengan A6 dan B5 dengan B6. Didapatkan bahwa kolom retrofit A5 dengan jarak sengkang $7 \mathrm{~cm}$ memiliki nilai modulus elastisitas dan kekakuan yang lebih tinggi sebesar 177,69 \% dan 145,54\% daripada kolom retrofit A6 yang memiliki jarak sengkang $11 \mathrm{~cm}$. Sedangkan kolom retrofit B5 dengan jarak sengkang $7 \mathrm{~cm}$ memiliki nilai modulus elastisitas dan kekakuan yang lebih rendah sebesar 4,12\% dan 4,69\% daripada kolom retrofit A6 yang memiliki jarak sengkang $11 \mathrm{~cm}$ yang mana seharusnya berdasarkan teori, untuk jarak sengkang yang lebih rapat memiliki nilai modulus elastisitas dan kekakuan yang lebih tinggi. Hal ini disebabkan oleh proses pengecoran yang tidak merata. Sedangkan nilai daktilitas kolom retrofit A5 jauh lebih efektif, dengan nilai efektifitas lebih besar $125,96 \%$ dibandingkan dengan kolom retrofit A6. Sedangkan untuk nilai daktilitas, kolom retrofit B5 memiliki nilai daktilitas yang lebih efektif juga sebesar 39,67\% daripada kolom retrofit B6.

3. Nilai efektifitas dari variasi jarak sengkang kolom diambil dari pertimbangan nilai gaya tekan maksimum dari peningkatan nilai gaya tekan dan daktilitas dari kolom kontrol ke kolom retrofit. Hal ini dikarenakan nilai kekakuan dan modulus elastisitas selalu berbanding lurus dengan gaya tekan maksimum, apabila gaya tekan maksimum kolom retrofit yang dibandingkan lebih besar maka kekakuan dan modulus elastisitas kolom retrofit tersebut akan lebih besar juga, begitu juga sebaliknya. Oleh karena itu nilai efektifitas diambil dari nilai gaya tekan maksimum dari peningkatan nilai gaya tekan dan daktilitas dari kolom kontrol ke kolom retrofit. Berdasarkan penelitian yang di peroleh dan di bandingkan dengan teori yang ada maka kolom retrofit dengan variasi jarak sengkang $7 \mathrm{~cm}$ (kolom retrofit A5 dan B5) lebih efektif dibandingkan dengan jarak sengkang $11 \mathrm{~cm}$ (kolom retrofit A6 dan B6). Hal ini dikarenakan semakin rapat jarak sengkang yang dipasang maka efek kekangan dari sengkang tersebut akan semakin besar pula, sehingga menyebabkan peningkatan gaya tekan dan daktilitas. Namun pada perbandingan variasi B5-B6 terdapat sedikit catatan yang mengakibatkan nilai kuat tekan lebih tinggi dari jarak sengkang yang lebih renggang. 


\subsection{Saran}

Saran yang bisa diberikan kepada peneliti yang ingin melanjutkan daripada penelitian ini antara lain:

1. Diperlukan penambahan jumlah kolom kontrol dari setiap benda uji dari pengecoran yang sama hal ini karena kolom asli tidak dilakukan pengujian dan untuk pengambilan data awal hanya di peroleh dari kolom kontrol yang di uji kuat tekan. Disarankan untuk setiap variasi kolom asli memiliki benda uji kolom kontrol sendiri yang akan digunakan sebagai perbandingan dalam nilai gaya tekan maksimum kolom.

2. Diperlukan alat dokumentasi lebih dari satu pada saat pengujian hal ini untuk menghindari terjadinya hal yang tidak diinginkan pada proses perekaman video, seperti baterai habis dan memori alat dokumentasi yang telah penuh sementara proses pengujian masih berjalan.

3. Perlu diperhatikan metode pengecoran pada saat penelitian Hal ini dikarenakan pada pengecoran mortar, diperoleh nilai kuat tekan yang jauh lebih tinggi dari nilai rencana kuat tekan seharusnya dikarenakan pada perencanaan pengadukan mortar menggunakan alat manual dan pada saat pengecoran benda uji menggunakan alat bantu concrete mixer.

4. Perlu diperhatikan saat penyetelan alat uji seperti LVDT pada saat pengujian, hal ini dikarenakan apabila alat LVDT tidak terpasang dengan benar maka pengujian akan gagal dan akan menghilangkan sampel yang telah di buat.

\section{DAFTAR PUSTAKA}

[1] Nawy, GE. 1985. Beton Bertulang - Suaru Pendekatan Dasar. Suryoatmono B, penerjemah. Bandung : PT. Refika Aditama. Terjemahan dari : Reinforced Concrete - A Fundamental Approach.

[2] Tjokrodimuljo, K., 2004, Teknologi Bahan Konstruksi, Buku Ajar, Jurusan Teknik Sipil dan Lingkungan Fakultas Teknik, Universitas Gadjah Mada Yogyakarta

[3] Morisco. 1999. Rekayasa Bambu. Nafiri Offset. Yogyakarta.

[4] Cusson, D. dan Paultre, P. 1995. Stress Strain Model for Confined High Strength Concrete. Jurnal of Structural Engineering. Vol. 121 (3), halaman $468-477$.

[5] Park,R \& Paulay,T. 1974. Reinforced Concrete Structures. New Zealand : Departement of Civil Engineering, University of Canterbury. 